\title{
DEMOCRACY AND ISLAMIC STUDIES AT PESANTREN
}

\author{
Munawir \\ STAIN Purwokerto \\ Jl. A. Yani 40-A, (+62-281) 635624, Purwokerto 53126 \\ E-mail: munawir.0510@gmail.com \\ HP. +62-87839973383
}

Abstrak: Demokrasi di sini adalah pengakuan semangat realitas plural, termasuk dalam studi Islam. Pendekatan indoktrinasi harus digunakan dalam studi Islam karena dengan pendekatan ini nilai-nilai Islam yang telah diyakini kebenaran dapat ditanamkan, sehingga setiap muslim bisa hidup sesuai dengan nilai-nilai ini. Ini tidak berarti bahwa model pendekatan demokrasi yang menekankan pada proses dan penalaran tidak dapat diterapkan dalam studi Islam. Dengan ini, studi Islam tradisi akan selalu kritis dianalisis. Dengan prinsip demokrasi, pesantren sebagai pintu masuk dari sistem pendidikan Islam harus selalu terbuka untuk menerapkan ideide demokratisasi yang baik, dalam gaya kepemimpinan, bahkan lebih dalam studi Islam.

Abstract: Democracy here is not democratization as governance system, but democracy as spirit confession to the plural reality, including in Islamic studies. Truly, undeniable that indoctrination approach have to be used in Islamic studies because with this approach Islamic values which have been believed the truth can be inculcated, so that every Moslem can live as according to this values. It doesn't mean that democratic approach model which emphasize at the process and reasoning cannot be applied in Islamic studies. Herewith, Islamic studies traditions will always critical analyzed, so that will protected from intellectual saturation process (intellectual suicide). With democracy principle, pesantren as entrance of Islamic education system shall be always open to apply the good democratization ideas, in leadership style, even more in Islamic studies.

Kata Kunci: Demokrasi,. Pesantren, Islamic Studies, Critical studies, kiai. 


\section{A. Preface}

These days, democracy becomes a movement that influencing global politics growth, since the end of $20^{\text {th }}$ century democracy appears as important issue in the world along globalization process (Esposito and Voll, 1999: 1). Globalization supports a big share to growing of democratization.

Globalization and democracy as two sides currency. Globalization which is marked by unlimited relation between countries- progressively open widely the reality of pluralistic. The only one correct system to arrange the reality of pluralistic nowadays is democracy which forwards the justice and equality principle, without democracy the domination and hegemony of the stronger on weak will be unobviable

Therefore, people pay more attention on democracy, and though initially democracy is a political movement, then democracy grows widely into entire human social life, including education. Democracy in education field become very importance because education, essentially is acculturation process and even the culture it self expanded by education. In this case, H.A.R. Tilaar said, "the crisis of society is reflection of education crisis" (Tilaar, 2000: 1). Also, John Dewey also said, "Education is a medium for growing the life of democracy" (Dewey, 1965: 81-99).

That's important relation between education and democracy; hence this paper will explore pesantren as one of Islamic education system in Indonesia evaluated from the aspect of its democratization. One question, is pesantren as Islamic education system supports democratization and what's the implication into Islamic studies.

\section{B. Pesantren and Democratization}

Based on its stratification, pesantren is the part of sub system of Islamic education. As for definition of pesantren as follows: 1) education system which is stimulated by the passion to implement the Islamic values, 2) education system which learn Islam studies, and 3) education system which covers both the things (Fadjar, 1998: 1). Its clear that pesantren is an education system takes Islamic values as a framework.

Thereby, if Islam as a religion taken as framework of education system in pesantren, hence become important to review democratization in this education system and looks for the relation of democracy and Islam.

Basically, relation between Islam and democracy is not too differing from other religion's relation with democracy. Suseno have a notion that attendance 
of religion will give two discourse; first, religion attributed to narrowness, dislike, conflict, murder, etc. Secondly, religion is benediction to society, because it's associated as kindness, peacefulness, affection, etc (Suseno, 1998: 158). Herewith, that religion provides possibilities for its refusing or accepting of democracy.

This possibility provides the relation may be full of conflict or become harmonious or even religion give the motivation for growing up democratization with its principles: justice and equation

It seems that the tight relation between religions and democracy is because the nat ure of theology: God's authority. The main principle in God's authority concept is that the only truth on God's hand, hence the main principles of democracy: plurality and parley are pursued.

Many aspects that pursue the relation between religion (Islam) and democracy are affected to Islamic education system (pesantren). The implication of principle God's authority as the only truth is applying indoctrination approach in education system of pesantren. Moreover, from leadership aspect, kiai as the leader of pesantren hence this principle make the leader (kiai) as light fingered of God that cannot be argued, debate, and is always assumed by correctness.

This matter clearly oppose against the principles of democracy, where do democratic education always emphasize at the process, (Zakaria, 2000: 482) and democratic leadership is the leadership that express people's will without authoritarian.

In my opinion, many pesantren applies undemocratic leadership and indoctrination approach. It seems from their cult to classic tradition of science. The tradition science in pesantren considered to something that sacral and will have the truism so that never in question how the tradition comes. Any doubt of this tradition means denial to Islamic law. The tradition of Islamic studies such as kalām (theology), fiqh (Islamic law/Islamic jurisprudence), and tașawwuf (mysticsm/Sufism) believed as the absolute thing (there shall no addition and reduction in it). Herewith, classical Islamic studies are accepted dogmatically, no creativity and innovation to develop it according to growth of human civilization.

For example in this case is woman's leadership in șalāt. In classical Islamic tradition, mentioned that a woman cannot become the leader (imām) for men (ma'mūm) (al-Asqalānì, 1969: 41). This opinion continues to be held, although there are many changes and development of woman discourse has differed now. This prohibition order believed as something that 'given' so that may not be questioned again since clearly the reason that woman is woman. 


\section{From Indoctrination Approach To Democratization Approach: A New Direction of Pesantren Education SYSTEM}

As told before, that indoctrination approach in Islamic education system is not only becoming the barrier for democratization process (pesantren), but also become resistor of the growth of Islam studies. It is true that the truth of Islam is may not questioned, however this truth is in infinite revelation discourse. As for the religion residing in the human history region of course its truth become relative, just like the truth of law in fiqh (Islamic jurisprudence) and $t a f s \bar{i}$ (interpretation/exegeses), since it is none other than product idea of human for giving the interpretation of the religion truism. In this area, democratization can be applied.

Its needed to differentiate between Islam as revelation and Islam as 'history product.'(Mudzhar, 2002: 19). The truth of revelation is absolute, but when it has been interpreted by human, this human interpretation on God's revelation becomes 'history product' what of course its truth become relative. In classical Islamic tradition any study none other than Moslem's effort to comprehend God's revelation. Therefore, all that science traditions have to be seen as ordinary 'history product' so that is the truth not automatically taken for granted.

Herewith, the pyramid structure of Islamic studies which are described as kalām (theology), fiqh (jurisprudence), and tașawwuf (mysticism/Sufism) none other than ordinary human's effort and interpretation which is indivisible from interference of political ideology expanding at moment, though it wrapped with passage of al-Qur' an or al-Hadits (Abdullah, 2006: 302). Political ideology at the time of Islamic science pyramid is formed must be influence the type, form, and the content of Islamic studies. Hereinafter, if classical Islamic studies tradition is a framework thought at the time, hence the tradition may to be studied, criticized, analyzed, and innovated so that seen which are normative and historical, purpose and appliance, universal and particular.

Democratic approach in education emphasizes the existence of relativity truth of knowledge, including human's religious idea. It isn't absolute at all that must be followed off hand, without critical question. The difference of civilization's challenge at the moment and human's experience at any place automatically also will cause the difference of human's thought. In this difference thought case, imam al-Syāfi ‘'i says, "Your opinion may be right but contain mistake, my opinion may be is wrong but contain truth". 
Democratic approach undoubtedly the existence of confession to other truth and possibility of own self mistake. This matter will make the new inventions (context of discovery) in Islamic studies tradition and always expand, while context of justification can be depressed become as small as possible. In this framework way of thinking, Islamic studies tradition doesn't will only reproduce the settled old paradigm, however criticized even possibly change it with new paradigm.

\section{Conclusion}

As conclusion, I require to affirm that democracy here is not democratization as governance system, but democracy as spirit confession to the plural reality, including in Islamic studies.

Truly, undeniable that indoctrination approach have to be used in Islamic studies because with this approach Islamic values which have been believed the truth can be inculcated, so that every Moslem can live as according to this values. It doesn't mean that democratic approach model which emphasize at the process and reasoning cannot be applied in Islamic studies. Herewith, Islamic studies traditions will always critical analyzed, so that will protected from intellectual saturation process (intellectual suicide).

With democracy principle, pesantren as entrance of Islamic education system shall be always open to apply the good democratization ideas, in leadership style, even more in Islamic studies. Because to apply Islam means striving to interpret God's revelation and doctrine according to space and time.

\section{REFERENCES}

Abdullah, Amin. 2006. Islamic Studies di Perguruan Tinggi. Yogyakarta: Pustaka Pelajar.

al-Asqalānī, Ibnu Ḥajar. 1969. Bulūgh al-Maram, Juz 2. Beyrūt: Dār al-Tsaqāfah al-Islāmiyyah.

Dewey, John. 1965. Democracy and Education. New York: Mac Millan.

Esposito, John L. and John O. Voll. 1999. Demokrasi di Negara-negara Muslim, (Problem dan Prospek), terj. Rahmani Astuti. Bandung: Mizan.

Fadjar, Malik. 1998. Madrasah dan Tantangan Modernitas. Bandung: Mizan. Mudzhar, M. Atho'. 2002. Pendekatan Studi Islam, (Dalam Teori dan Praktek). Yogyakarta: Pustaka Pelajar. 
Suseno, Franz Magnis. 1998. Mencari Makna Kebangsaan. Yogyakarta: Penerbit Kanisius.

Tilaar, H.A.R. 2000. Paradigma Baru Pendidikan Nasional. Jakarta: PT. Rineka Cipta.

Zakaria, Teuku Ramli. 2000. Pendekatan-pendekatan Nilai dan Implementasi dalam Pendidikan dan Kebudayaan, Nomor. 026, Tahun ke-6. 